\title{
Evaluation of the Salivary Flow Rate and pH in Patients with Recurrent Oral Ulcers
}

\author{
Mustafa Al-Ahmad, Basma Ezzat, Sukmasari S, Abdul Jabbar 0 \\ Kulliyyah of Dentistry, Internasional Islamic University Malaysia, Jalan Sultan Ahmad Shah, Indera Mahkota, \\ Kuantan, Pahang.
}

\section{ABSTRACT}

Introductions: Recurrent oral ulcers primarily effect mucosal surfaces and are among the most common chronic inflammatory diseases. Numerous studies to find the aetiopathogenesis have been conducted however the cause still remains unclear. Saliva is of utmostimportance for oral health maintenance. In current study, saliva was used as a diagnostic tool for comparison of salivary flow rate and $\mathrm{pH}$ in patients suffering from recurrent oral ulcers and control group. Materials and Methods: Saliva samples taken from 20 recurrent aphthous ulcer patients and 20 control (healthy) patients using a convient sampling method. Drooling method was used to collect unstimulated whole saliva sample. Pre-weighted specimen bottles were used and then weighed after sample collection on a graduated scale where as chair-side pH meter was used to determine the salivary $\mathrm{pH}$. Independent t-test and Pearson's correlation were performed. A p-value of less than 0.05 was considered statistically significance. Results: Positive correlation was found between the flow rate and $\mathrm{pH}$ in recurrent oral ulcer patients. Patients with recurrent oral ulcers had higher flow rate and $\mathrm{pH}$ compared to the control group. These effects were exaggerated in female patients with ulcers. Conclusions: Disturbances in salivary flow rate and $\mathrm{pH}$ were not significantly associated with recurrent oral ulcers.

KEYWORDS: salivary flow rate, salivary $\mathrm{pH}$, recurrent oral ulcers

\section{INTRODUCTION}

Recurrent oral ulcers, also known as recurrent apthous ulcers (RAU) are among the most common oral pathologies. RAU represents a painful mucosal condition affecting up to $25 \%$ of the general population. The onsets of this self-limiting condition can be often preceded by a prodromal burning sensation that lasts about 24-48 hours. RAU typically represents as repeated development of painful ulcers that completely heal between attacks, and clinically appear as small, shallow, rounded or oval well-defined ulcers with circumscribed, raised margins, surrounded by erythematous halo and yellowish-gray fibro

Corresponding author

Dr. Basma Ezzat Mustafa

Kulliyyah of Dentistry

IIUM Kuantan Campus

Jalan Sultan Ahmad Shah

Kuantan, Pahang.

Tel : 09-5705487

Email: alahmadbasma970@gmail.com membranous layer. Non-keratinized areas including buccal mucosa, lips, and soft palate are prone to RAU. ${ }^{1,2}$ A slight predominance of RAU among women and several predisposing factors have been proposed including nutritional factors, physiological stress, microbial factors, genetic predisposition and allergy to dietary constituents. Although the principal cause of RAU still remains unclear, it is suspected to occur by a group of aetiologies rather than a standalone factor. Environmental and genetic factors may collectively play a role in its aetiopathogenesis. ${ }^{3}$ RAU negatively impacts the oral health which in turn affects the qualityof life of the individuals suffering from this condition. ${ }^{2}$

Physical andchemical properties of saliva play an important part in maintenance of optimaloral tissue integrity and health. A variable room temperature exist a clinical finding in enhancement of salivary secretion if compared to contrlolled temperature. ${ }^{4,5}$ The mean daily saliva production of a healthy person ranges from 1-1.5 L. A parameter of salivary flow index can be utilized to classify stimulated and 
unstimulated saliva flow as very low, low or normal. ${ }^{6}$ Saliva plays a significant role to protect and repair oral mucosa. ${ }^{7}$ Salivary $\mathrm{pH}$ ranges from $6.20-7.60 \mathrm{pH}$ with $6.70 \mathrm{pH}$ being an average $\mathrm{pH}$. Saliva constitutes mainly of bicarbonate which has the ability to maintain the neutrality of saliva in oral cavity between $6.70-7.30 \mathrm{pH}$. The bicarbonate acts as a buffer to oppose acid production in the oral cavity, thus manipulating the salivary $\mathrm{pH}$. Literature suggests that $\mathrm{pH}$ level changes with flow rate. $^{8}$ where a higher $\mathrm{pH}$ is detected with an increment of salivary flow rate and vice versa. ${ }^{9,10}$ with significant sexual differences. ${ }^{7}$ Salivary $\mathrm{pH}$ of male RAU patients has been documented to be more acidic when compared to normal males. However, Al Taee in 2010 did not find significant difference of $\mathrm{pH}$ between genders. ${ }^{4,10,11}$

The saliva flow also eliminates carbohydrates timely which if metabolized by oral bacteriacan result in acid production altering oral $\mathrm{pH}$. With the rise of salivary flow rate, it has been found that bicarbonate concentration also markedly increases. ${ }^{12}$ making the buffer highly effective only at high salivary flow rate. ${ }^{7,13}$ Healthy individuals have $0.3 \mathrm{~mL} / \mathrm{min}$ salivary flow rate when not stimulated and variation in this parameter significantly affected by various components of saliva. To minimize the circadian effect, saliva should be obtained at the same time of the day . It has been suggested that maximum flow rate can be achieved during mid-afternoon. A salivary flow of less than $0.1 \mathrm{~mL} / \mathrm{min}$ is considered very low, 0.1 $0.25 \mathrm{~mL} / \mathrm{min}$ is considered low and $0.25-0.35 \mathrm{~mL} /$ min is considered normal. ${ }^{14}$ Altered salivary flow rate may suggest the pathogenesis of oral and dental disease, such as oral mucositis as seen in reduced salivary flow. ${ }^{15}$

Aim of current study is to determine relation between salivary flow rate and $\mathrm{pH}$ with recurrent oral ulcer.To investigate its role and possible relationship in the incidence and development of recurrent oral ulcer.

\section{MATERIALS AND METHODS}

Prior ethical clearance was granted by the ethical board of International Islamic University Malaysia (IIUM) (IREC), Kulliyyah of Dentistry Research Committee (KDRC). The aim of the study and confidentiality and privacy issueswere briefed to the respondents and written consent was obtained. The results represented in this study are from the respondents only and data obtained from this research was only used for this study only.

This study was of a quantitative type in sample size of 40 patients attended Kulliyyah of Dentistry IIUM Polyclinic. Convenience sampling method was used and the participants age ranging from 20 to 60 years was included in the study.Control group sample was matched with regard to socio-economic status, age, and gender. 20 patients having recurrent oral ulcers were assigned to case groupwhereas 20 healthy subjects represented the control group. The case group consisted of 6 males and 14 females meanwhile the control group consisted of 10 males and 10 females.

Patients who had current active lesion of recurrent oral ulcer and confirmation of chronic history of minor apthous ulcer, major apthous ulcer or herpetiform ulcer were included in case group. Patients included in case group were non-smoker (cigarettes, pipes, vapour), free from any systemic disease which can alter the saliva $\mathrm{pH}$ and salivary flow rate, not immuno-compromised, not pregnant, not on any chronic medication that could cause hypo -salivation and not denture or orthodontic appliance wearer.

The control group included the patients who had no previous history of the disease and did not have any current lesion of recurrent oral ulcer. Patients in the control group had no symptoms of any systemic disorder, had not used an orthodontic apparatus or were not prescribed any medications that can alter saliva $\mathrm{pH}$ and saliva flow rate, not smoking, and not pregnant.

Samples of whole unstimulated salivary flow rate were measured using drooling method. The subjects were instructed to abstain from any form of food consumption at least one hour prior to the examination time (between 10:00 AM and 4:00 PM). Before collection, Room temperature information was read from digital thermometer installed in dental clinics and was recorded,the participants were instructed to rinse orally with water. After swallowing all the saliva present in the mouth, they were instructed to expectorate newly accumulated saliva every 60 second for a period of 5 minutes in a pre-weighted disposable cup. Within this period, the 
participants were left undisturbed, sitting in a comfortable position, withthe head in upright position. Participants refrained from speaking to avoid anyconscious stimulation of oral musculature which could stimulate any saliva production.

The disposable cup containing saliva was placed in a precision balance (Mettler TLE 303E, Zurich, Switzerland) to determine the salivary flow rate. The difference between the pre-weighed value and after collection was recorded as salivary weight. The salivary weight was then divided by the duration of collection ( $5 \mathrm{~min}$ ) and the flow rate was recorded in $\mathrm{g} / \mathrm{min}$, which is equivalent to $\mathrm{mL} / \mathrm{min}$. It was demonstrated there was high correlation between weight and volume of unstimulated whole saliva, however volume measures were found less reliable. $^{16}$

A sample of $4 \mathrm{ml}$ mixed whole unstimulated saliva was dispensed in a sterilized plane tube and its $\mathrm{pH}$ was determined using the $\mathrm{pH}$ meter (Laqua, Horiba, PH 1100).

\section{Statistical analysis}

Mean and standard deviation were computed for the data. Statistical Package of Social Sciencesversion-15 for Windows was used for advanced statistics. Chisquare test and independent T-test were performed. A $p$-value of less than 0.05 was considered statistically significance.

\section{RESULT}

In this study, no statistically significant difference was observed in both salivary $\mathrm{pH}$ levels and flow rates between case and control group ( $\mathrm{t}$ value: 0.185, $\mathrm{p}<0.05$ ), (t value: 0.197, $\mathrm{p}<0.05$ ) as demonstrated in Table 1.

Flow rate of RAU male patients was lower than females, meanwhile in control group it was vice versa. Females in both RAU and control groups had more acidic salivary $\mathrm{pH}$. Both flow rate and $\mathrm{pH}$ had higher mean values in casegroup in comparison to the controls.

Table 1: Comparison of Salivary $\mathrm{pH}$ and salivary flow rate between test cases $(n=20)$ and control cases $(n=20)$

\begin{tabular}{|c|c|c|c|c|c|c|c|c|c|}
\hline Variables & \multicolumn{4}{|c|}{ Test cases } & \multicolumn{3}{|c|}{ Control cases } & p-value & t-value \\
\hline \multirow{6}{*}{$\begin{array}{l}\text { Salivary } \\
\text { flow rate }\end{array}$} & & $N$ & Mean & SD & $\mathrm{N}$ & Mean & SD & \multirow[t]{2}{*}{0.197} & \multirow[t]{2}{*}{0.423} \\
\hline & Total & 20 & 0.501 & 0.207 & 20 & 0.486 & 0.257 & & \\
\hline & Male & 10 & 0.55 & 0.257 & & & & \multirow[t]{2}{*}{1.162} & \multirow[t]{2}{*}{0.130} \\
\hline & Female & 10 & 0.42 & 0.253 & & & & & \\
\hline & Male & & & & 6 & 0.43 & 0.166 & \multirow[t]{2}{*}{-0.993} & \multirow[t]{2}{*}{0.167} \\
\hline & Female & & & & 14 & 0.53 & 0.221 & & \\
\hline \multirow[t]{4}{*}{$\mathrm{pH}$} & Total & 20 & 7.21 & 0.311 & 20 & 7.19 & 0.351 & 0.185 & 0.427 \\
\hline & Male & 10 & 7.28 & 0.397 & & & & \multirow[t]{2}{*}{1.126} & \multirow[t]{2}{*}{0.138} \\
\hline & Female & 10 & 7.10 & 0.295 & & & & & \\
\hline & Male & & & & 6 & 7.34 & 0.403 & 1.215 & 0.120 \\
\hline
\end{tabular}

* Significant at $\mathrm{P}<0.05$

Independent T-test (t-value)

two-tailed probability ( $p$-value)

Table 2: Comparison of salivary flow rate between the test cases and control cases in accordance with gender and age group

\begin{tabular}{|c|c|c|c|c|c|c|c|}
\hline Variables & & Case-control status & $\mathbf{N}$ & Mean & SD & "t-value" & "p-vlaue" \\
\hline \multirow{7}{*}{$\mathrm{pH}$} & \multirow{2}{*}{$\begin{array}{l}\text { Male } \\
(n=16)\end{array}$} & Control & 10 & 7.27 & 0.397 & \multirow[t]{2}{*}{0.288} & \multirow[t]{2}{*}{0.389} \\
\hline & & Case & 6 & 7.33 & 0.404 & & \\
\hline & \multirow{2}{*}{$\begin{array}{l}\text { Female } \\
(n-24)\end{array}$} & Control & 10 & 7.10 & 0.295 & \multirow[t]{2}{*}{0.461} & \multirow[t]{2}{*}{0.325} \\
\hline & & Case & 14 & 7.16 & 0.262 & & \\
\hline & \multirow[t]{2}{*}{ Age $<25$} & Control & 17 & 7.19 & 0.367 & \multirow[t]{2}{*}{0.263} & \multirow[t]{2}{*}{0.397} \\
\hline & & Cases & 17 & 7.22 & 0.308 & & \\
\hline & Age $>25$ & Control & 3 & 7.18 & 0.311 & -0.150 & 0.444 \\
\hline
\end{tabular}

* Significant at $P<0.05$

Independent T-test (t-value)

two-tailed probability ( $\mathrm{p}$-value) 
Table 2 and 3 did not reveal any significant difference in sex between case and control groups. There was also no difference in salivary flow rate and $\mathrm{pH}$ with age in both groups. In regards to room temperature, no significant difference was shown in both groups for flow rate and $\mathrm{pH}$, as demonstrated in Table 4 and 5.

Table 3: Comparison of salivary $\mathrm{pH}$ between the case and control groups in accordance with gender and age group

\begin{tabular}{|c|c|c|c|c|c|c|c|}
\hline Variables & & Case-control status & $\mathbf{N}$ & Mean & SD & t-value & p-value \\
\hline \multirow{8}{*}{$\mathrm{pH}$} & \multirow{2}{*}{$\begin{array}{l}\text { Male } \\
(n=16)\end{array}$} & Control & 10 & 7.27 & 0.397 & \multirow[t]{2}{*}{0.288} & \multirow[t]{2}{*}{0.389} \\
\hline & & Case & 6 & 7.33 & 0.404 & & \\
\hline & \multirow{2}{*}{$\begin{array}{l}\text { Female } \\
(n-24)\end{array}$} & Control & 10 & 7.10 & 0.295 & \multirow[t]{2}{*}{0.461} & \multirow[t]{2}{*}{0.325} \\
\hline & & Case & 14 & 7.16 & 0.262 & & \\
\hline & \multirow[t]{2}{*}{ Age $<25$} & Control & 17 & 7.19 & 0.367 & \multirow[t]{2}{*}{0.263} & \multirow[t]{2}{*}{0.397} \\
\hline & & Cases & 17 & 7.22 & 0.308 & & \\
\hline & \multirow[t]{2}{*}{ Age $>25$} & Control & 3 & 7.18 & 0.311 & \multirow[t]{2}{*}{-0.150} & \multirow[t]{2}{*}{0.444} \\
\hline & & Cases & 3 & 7.14 & 0.393 & & \\
\hline
\end{tabular}

* Significant at $\mathrm{P}<0.05$

Independent T-test (t-value)

two-tailed probability ( $\mathrm{p}$-value)

Table 4: Comparison of flow rate between case and control group in accordance with room temperature

\begin{tabular}{|c|c|c|c|c|c|c|c|}
\hline Variables & $\begin{array}{l}\text { Room } \\
\text { Temperature }\end{array}$ & Case-control status & $\mathbf{N}$ & Mean & SD & "t-value" & "p-value" \\
\hline \multirow{8}{*}{ Salivary flow rate } & \multirow[t]{2}{*}{$19-20 \mathrm{C}$} & Control & & - & - & \multirow[t]{2}{*}{-} & \multirow[t]{2}{*}{-} \\
\hline & & Case & 4 & 0.62 & 21 & & \\
\hline & \multirow[t]{2}{*}{$>20-21 \mathrm{C}$} & Control & 7 & 0.48 & 0.31 & \multirow[t]{2}{*}{0.020} & \multirow[t]{2}{*}{0.493} \\
\hline & & Case & 4 & 0.48 & 0.16 & & \\
\hline & \multirow[t]{2}{*}{$>21-22 C$} & Control & 11 & 0.47 & 0.21 & \multirow[t]{2}{*}{-0.050} & \multirow[t]{2}{*}{0.480} \\
\hline & & Cases & 9 & 0.47 & 0.25 & & \\
\hline & \multirow[t]{2}{*}{$>22-23 \mathrm{C}$} & Control & 2 & 0.59 & 0.48 & \multirow[t]{2}{*}{-0.453} & \multirow[t]{2}{*}{0.341} \\
\hline & & Cases & 3 & 0.47 & 0.14 & & \\
\hline
\end{tabular}

a. $t$ cannot be computed because at least one of the groups is empty

Table 5: Comparison of $\mathrm{pH}$ between case and control group in accordance with room temperature

\begin{tabular}{|c|c|c|c|c|c|c|c|}
\hline Variables & $\begin{array}{l}\text { Room } \\
\text { Temperature }\end{array}$ & Case-control status & $\mathbf{N}$ & Mean & SD & "t-value" & "p-value" \\
\hline \multirow{7}{*}{$\mathrm{pH}$} & \multirow[t]{2}{*}{$19-20 \mathrm{C}$} & Control & & - & - & \multirow[t]{2}{*}{-} & \multirow[t]{2}{*}{-} \\
\hline & & Case & 4 & 7.14 & 0.42 & & \\
\hline & \multirow[t]{2}{*}{$>20-21 \mathrm{C}$} & Control & 7 & 7.03 & 0.32 & \multirow[t]{2}{*}{0.020} & \multirow[t]{2}{*}{0.269} \\
\hline & & Case & 4 & 0.48 & 0.16 & & \\
\hline & \multirow[t]{2}{*}{$>21-22 \mathrm{C}$} & Control & 11 & 7.30 & 0.35 & \multirow[t]{2}{*}{-0.730} & \multirow[t]{2}{*}{0.238} \\
\hline & & Cases & 9 & 7.19 & 0.32 & & \\
\hline & $>22-23 C$ & Control & 2 & 7.16 & 0.45 & 1.085 & 0.179 \\
\hline
\end{tabular}

a. $t$ cannot be computed because at least one of the groups is empty. 
Table 6 shows that salivary flow rate was positively correlated to age (Pearson correlation of $r=0.132$ ) and $\mathrm{pH}(\mathrm{r}=0.244)$. $\mathrm{pH}$ was also positively correlated to temperature $(r=0.350)$. However, the $\mathrm{pH}$ was negatively correlated to age $(r=-0.198)$.

Table 6: Correlation Matrix of salivary $\mathrm{pH}$, salivary flow rate, room temperature and age of the patients $(n=40)$

\begin{tabular}{|c|c|c|c|c|c|}
\hline & & \multicolumn{4}{|c|}{ p Values } \\
\hline & & Age & $\begin{array}{l}\text { Salivary Flow } \\
\text { rate/min }\end{array}$ & $\mathrm{pH}$ & $\begin{array}{l}\text { Room } \\
\text { Temperature }\end{array}$ \\
\hline \multirow{4}{*}{$\frac{\tilde{D}}{\frac{\tilde{D}}{\tilde{\sigma}}}$} & Age & 1 & $\begin{array}{l}0.132 \\
(0.417)\end{array}$ & $\begin{array}{l}-0.198 \\
(0.220)\end{array}$ & $\begin{array}{l}-0.074 \\
(0.648)\end{array}$ \\
\hline & $\begin{array}{l}\text { Salivary Flow } \\
\text { rate }\end{array}$ & & 1 & $\begin{array}{l}0.224 \\
(0.165)\end{array}$ & $\begin{array}{l}-0.46 \\
(0.778)\end{array}$ \\
\hline & $\mathrm{pH}$ & & & 1 & $\begin{array}{l}0.350^{*} \\
(0.027) \\
\end{array}$ \\
\hline & $\begin{array}{l}\text { Room } \\
\text { Temperature }\end{array}$ & & & & 1 \\
\hline
\end{tabular}

Pearson correlation ' $r$ ' ( $p$ value)

\section{DISCUSSION}

Saliva has beenidentified as a valuable and reliable diagnostic tool to identify various diseases. ${ }^{6,15}$ Modern tools have deemed saliva as a non-invasive, safe and economical alternative to blood. Salivary biomarkers have increasingly gained importance in identifying complex diseases with the least invasive techniques and minimal resources of RNA and DNA are well preserved in saliva. However, use of saliva as a possible indicator of RAU is not common.

Current study aimed to evaluate salivary $\mathrm{pH}$ and flow rate in patients with RAU and to determine any relation between salivary flow rates with incidence of recurrent oral ulcer. There was no difference between the salivary flow rates of the case and control group. Few studies have been conducted to determine salivary flow rates and $\mathrm{pH}$ in recurrent oral ulcer patients. Vildan Erdem in 2013 observed that the mean salivary flow rate in oral ulcer patients was $1.44 \pm 0.52$ and the $\mathrm{pH}$ was $7.76 \pm 0.51$. The mean salivary flow rate in controls was $1.41 \pm 0.50$ and the $\mathrm{pH}$ was $7.18 \pm 0.46 .{ }^{17}$ They did not find any significant difference in salivary flow rates between the case and control groups, however significant difference existed for salivary $\mathrm{pH}$ which is in accordance to our findings. Salivary flow rate and $\mathrm{pH}$ were found higher in case group than in control groups but was not found statistically significant.

In the present study, RAU patients had higher levels of acidic saliva compared to control group although it was not statistically significant. This result was in accordance with several studies that demonstrated significant declination of $\mathrm{pH}$ values in RAU patients. ${ }^{18}$ On the contrary, Brawley found that resting saliva $\mathrm{pH}$ did not vary significantly in subjects of different ages ranging from 3 weeks to 101 years. Hence, the difference in salivary $\mathrm{pH}$ might be contributed to the variation of collection method and patients' dietary consumption. ${ }^{19}$

However, its clinical implicationshave not been fully understood as the alkaline saliva has been considered to be protective or aggressive medium. Al Taeein 2010 found a positive relation of acidic saliva in patients with RAU. According to gender, this study found that $\mathrm{pH}$ in female patients with RAU was more acidic than male RAU patients which was similar to the control group. However, this study was unable to determine a statistically significant difference in $\mathrm{pH}^{4}$

The contradiction in results probably can be attributed to the findings that salivary flow rate influences the $\mathrm{pH}$ of saliva. ${ }^{20}$ Variations in the rate of salivary flow could reversibly or irreversibly affect numerous physiological and pathological factors. A good salivary flow is known to protect against dental caries, abrasion, erosion and candidiasis. ${ }^{21}$ As salivary secretion is a complex process, different conditions can occur consequent to the variation of flow and its composition. 
This study chose unstimulated whole saliva as itrepresents basal rate of salivary flow, it primarily exists for about 14 hours a day and is responsible for protection and maintenance of oral health and reflects the physiological status of the oral cavity. Resting whole saliva is a mixture of glandular secretions in the absence of exogenous stimuli. Therefore, salivary gland status can be accurately assessed by the study of unstimulated salivary secretion meanwhile stimulated saliva is more beneficial in studying functional reserve. ${ }^{15}$ However, truely unstimulated saliva is often difficult to collect due to numerous stimuli effecting environmentally, which could possibly influence salivary flow rates.

In conducting the study, it is desirable to note that flow rate exhibit both daily and seasonal variation, with peak flow occurring at mid-afternoon. ${ }^{22}$ Bloomfield and Huck concluded that the normal variation was the same as the diurnal variation. Farga found that saliva was reported to be very acidic in the morning and more alkaline in the afternoon. ${ }^{23}$ Hence, differences between the present values and those reported in previous literatures might be influenced by this circadian rhythm, as procedures of saliva collection were carried out at a wide range of time; from 10 am to 4 pm.

In the case of decreased salivary flow rate, salivary $\mathrm{pH}$ will get low by decreased bicarbonate secretion and this declination in salivary bicarbonate will in turn further decrease the salivary $\mathrm{pH}$. Since the sample size was small, the salivary flow rate and salivary $\mathrm{pH}$ could drastically vary, thus limiting the present study. ${ }^{15}$ Brozovic in 2001 found that salivary flow rates did not differ significantly between acute RAU cases (either minor or major), during remission period and controls. ${ }^{16}$ However no statistically significant differences were found between flow rate in active lesion and acquiescence. Similar flow rates were measured in patients with RAU in comparison to individuals with no prior history of such lesions. ${ }^{24}$

This study did not demonstrate any significant difference among the whole unstimulated flow rate between case and control groups. Percival in 1994 found that secretion rates decreased in relation to age. He found that mean flow rates of unstimulated and whole saliva were significantly lower in females subjects $(p<0.005) .{ }^{24}$ In contrast, de Oliveira conducted a study and did not find any significant difference in salivary flow mean values between genders. ${ }^{16}$ Quantitative changes in saliva did not seem to play a role in the course of minor recurrent apthous ulcer. However, severe cases of minor recurrent apthous ulcer, which are characterized by the presence of more than two ulcers in a single attack and a very frequent recurrence, may be accompanied by higher saliva production which may represent a reactive response towards the active presence of recurrent apthous ulcer in the mouth. Binnal in 2014 also suggested that apthous ulcer might be one of the factors of minor sialorrhea which is excessive salivation which results from the local irritation it caused. ${ }^{25}$

Age-related, evidence shows that maturation of central control mechanism and progressive replacement of salivary gland tissue by far and atrophy of acinar cells caused the flow rate to increase with age but slows down after 29 years of age. Hence, this supports the findings where there is no statistical difference between both groups found in this study. ${ }^{19}$

We found that salivary $\mathrm{pH}$ was positively influenced due to the temperature which in turn influences on the measuring sensor used. Accuracy and speed of response of the electrode is diminished by the temperature effects. ${ }^{26}$ Therefore, the statistical significance could be possibly achieved if the temperature was set at the same during evaluation of the salivary $\mathrm{pH}$ hence decreasing the procedural errors and increase the reliability of the result.

The major flaw and limitation of this study might be its small sample size. Since, reports regarding unstimulated flow rate and $\mathrm{pH}$ have been scarce. There is an evergrowing interest for evaluation of saliva as a diagnostic tool. Present study provides information pertaining to flow rate and $\mathrm{pH}$ in patients with RAU in comparison to the healthy subjects. Hence, for more accuracy and improved validation, a bigger sample size is warranted in future studies.

\section{CONCLUSION}

In conclusion, the current study did not reveal any significant difference in patients with recurrent apthous ulcer and healthy subjects. Even though 
higher flow rates and $\mathrm{pH}$ seen in case group with more acidic saliva and higher salivary flow rate observed in female patients; salivary flow rate and $\mathrm{pH}$ does not establish any association with recurrent oral ulcers.

\section{Declaration of Interest}

The authors declare no conflict of interest.

\section{Contribution of Authors}

The authors declare that this work was done by the authors named in this article and all liabilities pertaining to claims relating to the content of this article will be borne by them.

\section{REFERENCES}

1. Saikaly SK, Saikaly TS, Saikaly LE. Recurrent aphthous ulceration: a review of potential causes and novel treatments. J Dermatol Treat 2018; 38:1-11.

2. Natah SS, Konttinen YT, Enattah NS, Ashammakhi N, Sharkey KA, HäyrinenImmonen R. Recurrent aphthous ulcers today: a review of the growing knowledge. Int J Oral Maxillofac Surg 2004; 33:221-34.

3. Abbass A-T. Determination of Salivary $\mathrm{pH}$ in patients with Recurrent Aphthous Ulceration (RAU). Alrafidain Dent J 2010; 10:1-4.

4. Foglio-Bonda PL, Brilli K, Pattarino F, FoglioBonda A. Salivary flow rate and $\mathrm{pH}$ in patients with oral pathologies. Eur Rev Med Pharmacol Sci 2017; 21:369-74.

5. Mandel ID. The diagnostic uses of saliva. J Oral Pathol Med 1990; 19:119-25.

6. Foglio-Bonda PL, Migliario M, Rocchetti V, Pattarino F, Foglio-Bonda A. Daily and annually variation of unstimulated whole saliva flow rate and $\mathrm{pH}$ and their relation with body profile in healthy young adults. Eur Rev Med Pharmacol Sci 2013; 17:2538-45.

7. Bardow A, Moe D, Nyvad B, Nauntofte B. The buffer capacity and buffer systems of human whole saliva measured without loss of $\mathrm{CO} 2$. Arch Oral Biol 2000; 45:1-12.

8. Yeh CK, Johnson D a, Dodds MW, Sakai S, Rugh JD, Hatch JP. Association of salivary flow rates with maximal bite force. J Dent Res 2000; 79:1560-5.

9. Larsen MJ, Jensen AF, Madsen DM, Pearce EIF.
Individual variations of $\mathrm{pH}$, buffer capacity, and concentrations of calcium and phosphate in unstimulated whole saliva. Arch Oral Biol 1999; 44:111-7.

10. Kim Y, Choi YS, Baek KJ, Yoon S-H, Park HK, Choi $Y$. Mucosal and salivary microbiota associated with recurrent aphthous stomatitis. BMC Microbiol 2016; 16:57.

11. Sah K, Grover N, Chandra S, Singh R, Kanwar A. Long-term effect of tobacco on resting whole mouth salivary flow rate and $\mathrm{pH}$ : An institutional based comparative study. Eur J Gen Dent 2013;2:296.

12. Baliga S, Muglikar S, Kale R. Salivary $\mathrm{pH}$ : A diagnostic biomarker. J Indian Soc Periodontol 2013; 17:461.

13. De Almeida PDV, Grégio AMT, Machado MÂN, De Lima AAS, Azevedo LR. Saliva composition and functions: A comprehensive review. J Contemp Dent Pract 2008;9:72-80.

14. Singh $M$, Yadav $P$, Ingle N, Ingle E, Kaur N. Effect of long-term smoking on salivary flow rate and salivary $\mathrm{pH}$. J Indian Assoc Public Heal Dent 2015; 13:11.

15. Martinez KDO, Mendes LL, Alves JB. Secretory A immunoglobulin, total proteins and salivary flow in Recurrent Aphthous Ulceration. Braz J Otorhinolaryngol 2007; 73:323-8.

16. Erdem V, Yildiz M, Erdem T. The evaluation of saliva flow rate, $\mathrm{pH}$, buffer capacity, microbiological content and indice of decayed, missing and filled teeth in behçet's patients. Balkan Med J 2013;30: 211-4.

17. Maurice M, Mikhail W, Aziz M, Barsoum M. Aetiology of recurrent aphthous ulcers (RAU). J Laryngol Otol 1987; 101:917-20.

18. Wu KP, Ke J-Y, Chung C-Y, et al. Relationship between unstimulated salivary flow rate and saliva composition of healthy children in Taiwan. Chang Gung Med J 2008; 31:281-6.

19. Kaufman E, Lamster IB. the Diagnostic Applications of Saliva- a Review. Crit Rev Oral Biol Med 2002; 13:197-212.

20. Dawes C. Salivary flow patterns and the health of hard and soft oral tissues. J Am Dent Assoc 2008;139 Suppl:18S-24S.

21. Tortora GJ, Derrickson B. Principles of Anatomy and Physiology. John Wiley \& Sons; 2008 Apr 11.

22. Hill SP. Do gorillas regurgitate potentiallyinjurious stomach acid during "regurgitation and reingestion?” Anim Welf. 2009; 18:123-7. 
23. Percival RS, Challacombe SJ, Marsh PD. Flow rates of resting whole and stimulated parotid saliva in relation to age and gender. J Dent Res 1994; 73:1416-20.

24. Binnal A , Ahmed J, Shenoy N , Denny C ML. Dental Management Of Patients Suffering From Drooling: Review And Update. Int J Adv Res 2014; 2:615-8.

25. Barron J, Ashton C, Geary L. The Effects of temperature on $\mathrm{pH}$ measurement. TSP 2005; 1:1-7. 